\title{
Sardiniella urbana gen. et sp. nov., a new member of the Botryosphaeriaceae isolated from declining Celtis australis trees in Sardinian streetscapes
}

\author{
Linaldeddu BT ${ }^{1}$, Alves $\mathrm{A}^{2}$ and Phillips $\mathrm{AJL}^{3}$ \\ ${ }^{1}$ Dipartimento di Agraria, Sezione di Patologia vegetale ed Entomologia, Università degli Studi di Sassari, Viale Italia \\ 39, 07100 Sassari, Italy \\ ${ }^{2}$ Departamento de Biologia, CESAM, Universidade de Aveiro, 3810-193 Aveiro, Portugal \\ ${ }^{3}$ Biosystems and Integrative Sciences Institute, Faculty of Science, University of Lisbon, Campo Grande, 1749-016 \\ Lisbon, Portugal
}

Linaldeddu BT, Alves A, Phillips AJL 2016 - Sardiniella urbana gen. et sp. nov., a new member of the Botryosphaeriaceae isolated from declining Celtis australis trees in Sardinian streetscapes. Mycosphere 7(7), 893-905, Doi 10.5943/mycosphere/si/1b/5

\begin{abstract}
During a survey carried out in 2013 throughout the streets of Sassari (Sardinia, Italy) aimed at clarifying the causes of a decline affecting European hackberry, a collection of a Botryosphaeriaceous taxon was isolated from 14 trees showing sunken cankers with wedge-shaped necrotic sectors and a progressive dieback of shoots and branches as well as collar rot and stem exudates. Although morphologically similar to Diplodia and Dothiorella, these strains differed from all known species of Botryosphaeriaceae in their colony appearance and conidial shapes. A phylogenetic analysis based on combined LSU, ITS and tefl- $\alpha$ sequence data showed that these strains form a distinct lineage within the Botryosphaeriaceae. Based on molecular phylogeny and morphology, a new genus named Sardiniella is herein introduced to accommodate the new taxon Sardiniella urbana. Pathogenicity was verified by wound inoculation of 3 year-old seedlings of European hackberry using four different strains. All strains caused sunken cankers and necrotic lesions on inner bark and sap wood tissues in the stems of inoculated seedlings and in all cases the fungus was successfully re-isolated, fulfilling Koch's postulates. Results from the pathogenicity test suggest that this new species is directly involved in the aetiology of the observed decline in European hackberry trees as well as representing a potential risk to public safety in urban environments.
\end{abstract}

Key words - urban forestry - emerging pathogen - morphology - phylogeny - taxonomy

\section{Introduction}

Botryosphaeriaceae species are widely recognized as important fungal plant pathogens worldwide. In particular, several species within this family represent a growing threat to agricultural and forest ecosystems in Mediterranean climate (Gramaje et al. 2012, Lynch et al. 2013, Linaldeddu et al. 2016). The family currently comprises 22 phylogenetically well-defined genera and over one hundred species known from culture and for which molecular data are available in public database (Crous et al. 2013, Phillips et al. 2013, Hyde et al. 2014, Crous et al. 2015). Over the last decade, Botryosphaeriaceae has undergone important revision and several new 
species and genera have been introduced chiefly on the basis of combined morphological and multiple gene sequence data (Crous et al. 2006, Phillips et al. 2008, Rojas et al. 2008, Liu et al. 2012, Slippers et al. 2013, Hyde et al. 2014, Crous et al. 2015).

Most of the studies on species of Botryosphaeriaceae have focused on woody hosts of economic importance such as eucalypt, grapevine, mango and pine (De Wet et al. 2002, Taylor et al. 2009, Marques et al. 2013, Linaldeddu et al. 2015), while very few studies have investigated species occurrence and distribution as well as damage caused by these fungi on ornamental trees in urban environments (Begoude et al. 2010, Mayorquin et al. 2012). Recently, Zlatković et al. (2016) reported ten Botryosphaeriaceae species associated with extensive dieback and mortality of various ornamental trees and shrubs in a small geographical area in the western Balkans. They emphasized that diseases caused by Botryosphaeriaceae could be linked to adverse abiotic factors as well as other stresses typical of urban environments, such as air pollution and pruning activity.

In 2013, during a survey carried out throughout the main streets of Sassari (Sardinia, Italy) aimed at clarifying the causes of a decline affecting European hackberry (Celtis australis L.), a collection of botryosphaeriaceous strains was isolated from trees showing V-shaped cankers and a progressive dieback of shoots and branches as well as collar rot and stem exudates. Although morphologically similar to Diplodia and Dothiorella, these strains differed in their colony appearance, conidial shape and DNA sequence data (ITS and tefl- $\alpha$ ) from all known species of Botryosphaeriaceae.

Therefore, the aim of this study was to clarify the morphology, phylogeny, taxonomy and pathogenicity of these fungal isolates collected from European hackberry. This was achieved using a polyphasic approach based on the combination of molecular sequence data of the large subunit (LSU) rDNA gene, ITS and tefl- $\alpha$ regions and anamorph morphology. Furthermore, the pathogenicity of this new Botryosphaeriaceae member was tested on 3-year-old seedlings of European hackberry.

\section{Materials \& Methods}

\section{Isolates and morphology}

Isolates used in this study were obtained from 14 declining European hackberry trees planted along 3 streetscapes in the city of Sassari (Sardinia, Italy). A total of 22 symptomatic samples were collected. Samples were taken to the laboratory and the outer bark surface tissue was cut away with a scalpel. Longitudinal and transversal cuts from symptomatic samples revealed internal symptoms. Isolations were made from chips of inner bark and xylem tissue $\left(\sim 5 \mathrm{~mm}^{2}\right)$ removed from the margin of necrotic lesions with a sterile scalpel. All chips were cultured on potato dextrose agar (PDA, Oxoid Ltd., Basingstoke, UK) in Petri-dishes. After incubation at $25^{\circ} \mathrm{C}$ for 5-7 days in the dark, fungal colonies were sub-cultured onto half-strength PDA supplemented with autoclaved holm oak twigs and incubated at room temperature with natural daylight until pycnidia developed.

Colony growth characteristics including surface and reverse colony appearance were recorded after 7 days of incubation at $25{ }^{\circ} \mathrm{C}$ in the dark on PDA, malt extract agar (MEA, $20 \mathrm{~g} / \mathrm{L}$ malt extract, $20 \mathrm{~g} / \mathrm{L}$ agar, Oxoid Ltd.), and oatmeal agar (OA, $72.5 \mathrm{~g} / \mathrm{L}$, Sigma-Aldrich). Cardinal temperatures for growth were determined on plates of PDA incubated at 5, 10, 15, 20, 25, 30, 35 and $40{ }^{\circ} \mathrm{C}\left( \pm 0.5{ }^{\circ} \mathrm{C}\right)$ in the dark. Five replicate plates of four isolates were made and colony diameters were measured after 4 days. For microscopy, the contents of conidiomata were dissected and mounted in $100 \%$ lactic acid. Measurements of conidiogenous cells and conidia were made with the Leica IM 500 measurement module from images recorded with the $\times 100$ objective on a Leica DFC 320 digital camera. Spore dimensions are presented as mean values of 50 conidia with extreme values in parentheses. Dimensions of other structures are given as means of at least 20 measurements.

Representative isolates were stored on PDA slants under oil in the culture collection of the Sez. di Patologia vegetale ed Entomologia, Dipartimento di Agraria at the University of Sassari. A representative culture was deposited at the Centraalbureau voor Schimmelcultures (CBS), Utrecht, 
the Netherlands and nomenclatural data in MycoBank (www.MycoBank.org; Crous et al. 2004) and Faces of Fungi (www.facesoffungi.org; Jayasiri et al. 2015) databases. The holotype was lodged with the herbarium of Instituto Nacional de Investigação Agrária e Veterinária I.P., Oeiras, Portugal (LISE).

\section{DNA extraction, PCR amplification and sequencing}

Genomic DNA was extracted from 5-day-old cultures grown on PDA at $25^{\circ} \mathrm{C}$ using Instagene Matrix (BioRad Laboratories, Hercules, California, USA). The entire internal transcribed spacer (ITS) region of the ribosomal DNA, including the 5.8S rRNA gene, was amplified and sequenced using primers ITS1 and ITS4 (White et al. 1990), a partial sequence of the 28S rDNA gene (LSU) region was amplified and sequenced using primers NL1 and NL4 (O'Donnell 1993), whereas part of the tefl- $\alpha$ gene encoding translation elongation factor 1 alpha was amplified and sequenced with primers EF446f and EF1035r (Inderbitzin et al. 2010). PCR amplification was carried out as described by Linaldeddu et al. (2013) and the products were purified using the EUROGOLD gel extraction kit according to the manufacturer's instructions (EuroClone S.p.A., Pero, Italy). Both strands were sequenced by BMR Genomics DNA sequencing service (www.bmr-genomics.it). Sequences were edited with FinchTV v1.4.0 (Geospiza, Inc., Seattle, Washington, USA; http://www.geospiza.com/finchtv) and compared with sequences deposited in GenBank using the BLAST algorithm (http://blast.ncbi.nlm.nih.gov). New sequences were deposited in GenBank (Table 1). Alignments and trees are in TreeBase with study ID S19467.

\section{Phylogenetic analyses}

The ITS, LSU and tefl- $\alpha$ sequences of the isolates obtained in this study were combined and aligned with sequences of 42 taxa retrieved from GenBank, representing 18 genera of the family Botryosphaeriaceae. Sequence alignments were performed with ClustalX v. 1.83 (Thompson et al. 1997), using the following parameters: pairwise alignment parameters (gap opening $=10$, gap extension $=0.1$ ) and multiple alignment parameters (gap opening $=10$, gap extension $=0.2$, transition weight $=0.5$, delay divergent sequences $=25 \%$ ). Alignments were checked and manual adjustments made if necessary using BioEdit v. 7.2 .5 (Hall 1999). Maximum likelihood (ML) analyses were done using MEGA6 (Tamura et al. 2013) using the best fitting DNA evolution model determined by the program. ML analyses were performed on a Neighbour-Joining starting tree automatically generated by the software. Nearest-Neighbour-Interchange (NNI) was used as the heuristic method for tree inference and 1000 bootstrap replicates were performed. The robustness of the trees was evaluated by 1000 bootstrap replications. Saccharata proteae was used as outgroup to root the tree and that was visualised with TreeView v. 1.6.6 (Page 1996).

Table 1 Isolates included in the phylogenetic analyses. Type species of each genus are given in bold typeface and newly generated sequences are indicated in italics.

\begin{tabular}{|c|c|c|c|c|}
\hline \multirow{2}{*}{ Species } & \multirow{2}{*}{ Strain } & \multicolumn{3}{|c|}{ GenBank accession number } \\
\hline & & LSU & ITS & tefl- $\alpha$ \\
\hline Barriopsis fusca & CBS 174.26 ex-type & DQ377857 & EU673330 & EU673296 \\
\hline \multirow[t]{2}{*}{ Botryobambusa fusicoccum } & MFLUCC 11-0143 ex-type & JX646809 & JX646792 & JX646857 \\
\hline & MFLUCC 11-0657 & JX646810 & JX646793 & JX646858 \\
\hline Botryosphaeria agaves & MFLUCC 11-0125 ex-neotype & JX646808 & JX646791 & JX646856 \\
\hline Botryosphaeria corticis & CBS 119047 ex-epitype & EU673244 & DQ299245 & EU017539 \\
\hline Botryosphaeria dothidea & CBS 115476 ex-type & AY928047 & AY236949 & AY236898 \\
\hline \multirow[t]{2}{*}{ Cophinforma atrovirens } & MFLUCC 11-0425 ex-type & JX646817 & JX646800 & JX646865 \\
\hline & CBS 117444 & DQ377855 & KF531822 & KF531801 \\
\hline Diplodia cupressi & CBS 168.87 ex-type & EU673263 & DQ458893 & DQ458878 \\
\hline Diplodia mutila & CBS 112553 & AY928049 & AY259093 & AY573219 \\
\hline Diplodia rosulata & CBS 116470 ex-type & DQ377896 & EU430265 & EU430267 \\
\hline Diplodia sapinea & CBS 393.84 ex-epitype & DQ377893 & DQ458895 & DQ458880 \\
\hline
\end{tabular}




\begin{tabular}{|c|c|c|c|c|}
\hline \multirow{2}{*}{ Species } & \multirow{2}{*}{ Strain } & \multicolumn{3}{|c|}{ GenBank accession number } \\
\hline & & LSU & ITS & tefl- $\alpha$ \\
\hline$\overline{\text { Diplodia seriata }}$ & CBS 112555 ex-epitype & AY928050 & AY259094 & AY573220 \\
\hline Diplodia tsugae & CBS 418.64 ex-isotype & DQ377867 & DQ458888 & DQ458873 \\
\hline Dothiorella iberica & CBS 115041 ex-type & AY928053 & AY573202 & AY573222 \\
\hline Dothiorella prunicola & CBS 124723 ex-type & EU673232 & EU673313 & EU673280 \\
\hline Dothiorella sarmentorum & IMI 63581b ex-type & AY928052 & AY573212 & AY573235 \\
\hline \multirow[t]{2}{*}{ Endomelanconiopsis endophytica } & CBS 120397 ex-type & EU683629 & EU683656 & EU683637 \\
\hline & CBS 122550 & EU683634 & EU683664 & EU683645 \\
\hline Endomelanconiopsis microspora & CBS 353.97 ex-type & EU683628 & EU683655 & EU683636 \\
\hline Eutiarosporella tritici & CBS 118719 ex-type & DQ377941 & KF531830 & KF531809 \\
\hline Lasiodiplodia crassispora & CBS 118741 ex-type & DQ377901 & DQ103550 & EU673303 \\
\hline Lasiodiplodia gonubiensis & CBS 115812 ex-type & DQ377902 & AY639595 & DQ103566 \\
\hline Lasiodiplodia rubropurpurea & CBS 118740 ex-type & DQ377903 & DQ103553 & DQ103553 \\
\hline Lasiodiplodia theobromae & CBS 164.96 ex-neotype & EU673253 & AY640255 & AY640258 \\
\hline Lasiodiplodia venezuelensis & CBS 118739 ex-type & DQ377904 & DQ103547 & EU673305 \\
\hline \multirow[t]{2}{*}{ Macrophomina phaseolina } & CBS 162.25 & DQ377905 & KF531826 & KF531803 \\
\hline & CBS 227.33 & DQ377906 & KF531825 & KF531804 \\
\hline Marasasiomyces karoo & CBS 118718 ex-type & DQ377939 & KF531828 & KF531807 \\
\hline \multirow[t]{2}{*}{ Melanops tulasnei } & CBS 116805 & FJ824764 & FJ824769 & FJ824774 \\
\hline & CBS 116806 & FJ824765 & FJ824770 & FJ824775 \\
\hline Neodeightonia phoenicum & CBS 122528 ex-type & EU673261 & EU673340 & EU673309 \\
\hline Neodeightonia subglobosa & CBS 448.91 ex-type & DQ377866 & EU673337 & EU673306 \\
\hline Neofusicoccum arbuti & CBS 116131 ex-type & DQ377915 & AY819720 & KF531792 \\
\hline Neofusicoccum luteum & CBS 110299 ex-type & AY928043 & AY259091 & AY573217 \\
\hline Neofusicoccum mangiferae & CBS 118531 & DQ377920 & AY615185 & DQ093221 \\
\hline Neofusicoccum parvum & CMW 9081 ex-type & AY928045 & AY236943 & AY236888 \\
\hline \multirow[t]{2}{*}{ Neoscytalidium hyalinum } & CBS 145.78 ex-isotype & DQ377922 & KF531816 & KF531795 \\
\hline & CBS 251.49 & DQ377923 & KF531819 & KF531797 \\
\hline \multirow[t]{2}{*}{ Phaeobotryon mamane } & CPC 12440 ex-type & EU673248 & EU673332 & EU673298 \\
\hline & СРC 12264 & DQ377898 & EU673331 & EU673297 \\
\hline \multirow[t]{2}{*}{ Pseudofusicoccum stromaticum } & CBS 117448 ex-type & DQ377931 & AY693974 & AY693975 \\
\hline & CBS 117449 & DQ377932 & DQ377932 & DQ436936 \\
\hline Saccharata proteae & CBS 115206 & DQ377882 & KF531812 & KF531789 \\
\hline \multirow[t]{4}{*}{ Sardiniella urbana } & BL179 = CBS 141580 ex-type & KX379676 & KX379674 & KX379675 \\
\hline & BL180 & KX379679 & KX379677 & KX379678 \\
\hline & BL181 & KX379682 & KX379680 & KX379681 \\
\hline & BL182 & KX379685 & KX379683 & KX379684 \\
\hline Spencermartinsia citricola & ICMP 16828 ex-type & EU673323 & EU673242 & EU673290 \\
\hline Spencermartinsia mangiferae & CBS 500.72 & EU673237 & EU673318 & EU673285 \\
\hline Spencermartinsia plurivora & CBS 117006 & EU673236 & AY905555 & AY905562 \\
\hline Spencermartinsia viticola & CBS 117009 ex-type & AY905554 & DQ377873 & AY905559 \\
\hline Sphaeropsis citrigena & ICMP 16812 ex-type & EU673246 & EU673328 & EU673294 \\
\hline Sphaeropsis eucalypticola & MFLUCC 11-0579 ex-type & JX646819 & JX646802 & JX646867 \\
\hline Sphaeropsis porosa & CBS 110496 ex-type & DQ377894 & AY343379 & AY343340 \\
\hline Sphaeropsis visci & CBS 186.97 & DQ377868 & EU673325 & EU673293 \\
\hline
\end{tabular}

Acronyms of culture collections: CBS: Centraalbureau voor Schimmelcultures, The Netherlands; CMW: M.J. Wingfield, FABI, University of Pretoria, South Africa; CPC: Collection of Pedro Crous housed at CBS; ICMP: International Collection of Micro-organisms from Plants, Landcare Research, New Zealand; IMI: CABI Bioscience, Egham, UK; MFLUCC: Mae Fah Luang University Culture Collection, Chiang Rai, Thailand; BL: B.T. Linaldeddu culture collection housed at Dipartimento di Agraria, Università di Sassari, Italy. 

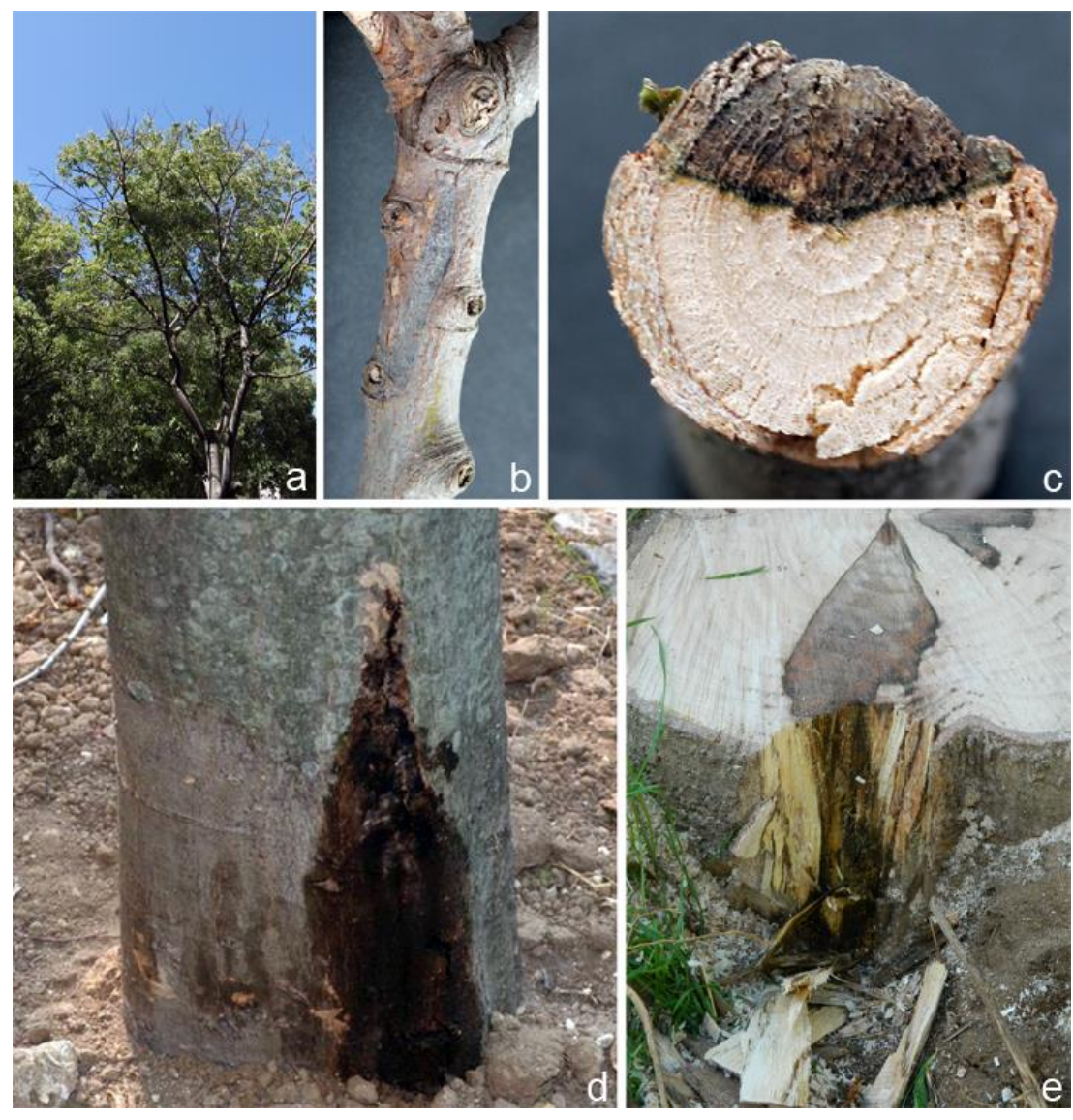

Fig. 1 - Main symptoms on European hackberry trees growing on a street verge. Progressive dieback of twigs and branches (a); branch with bark necrosis visible at level of a sunken cankers (b); cross section of a branch showing a characteristic wedge-shaped necrotic sector (c); an active sunken canker in the trunk wet with blackish exudates (d); cross section showing extensive necrotic lesion of xylem tissues corresponding to a canker (e).

\section{Pathogenicity test}

The pathogenicity of the four isolates investigated in this study, was tested on 3-year-old European hackberry seedlings grown in plastic pots $(10 \mathrm{~cm}$ diameter, 1.51 volume). Ten seedlings were inoculated with each isolate, and ten seedlings were used as control. The inoculated region of the stem was surface-disinfected with $70 \%$ ethanol and a small piece of outer and inner bark was removed with a flamed scalpel and replaced with an agar-mycelium plug taken from the margin of an actively growing colony on PDA. The inoculation site was covered with cotton wool soaked in sterile water and wrapped in a piece of aluminum foil secured with masking tape. Controls were inoculated with a sterile PDA plug applied as described above. Inoculated seedlings were kept in the laboratory at $18-26^{\circ} \mathrm{C}$ in natural daylight for 40 days. At the end of experimental period, the outer bark was carefully removed with a scalpel and the length of necrotic lesion surrounding each inoculation site was measured. Re-isolation of the inoculated strains was attempted by transferring onto PDA 10 pieces of inner bark and wood taken from around the margin of each lesion. Cultures were grown in daylight and room temperature until fungal colonies developed.

\section{Statistical analyses}

Pathogenicity assay data were checked for normality and then subjected to analysis of variance (ANOVA). Significant differences among mean values were determined using Fisher's least significant differences multiple range test $(\mathrm{P}=0.05)$ after one-way ANOVA using XLSTAT software (Addinsoft, Paris, France). 


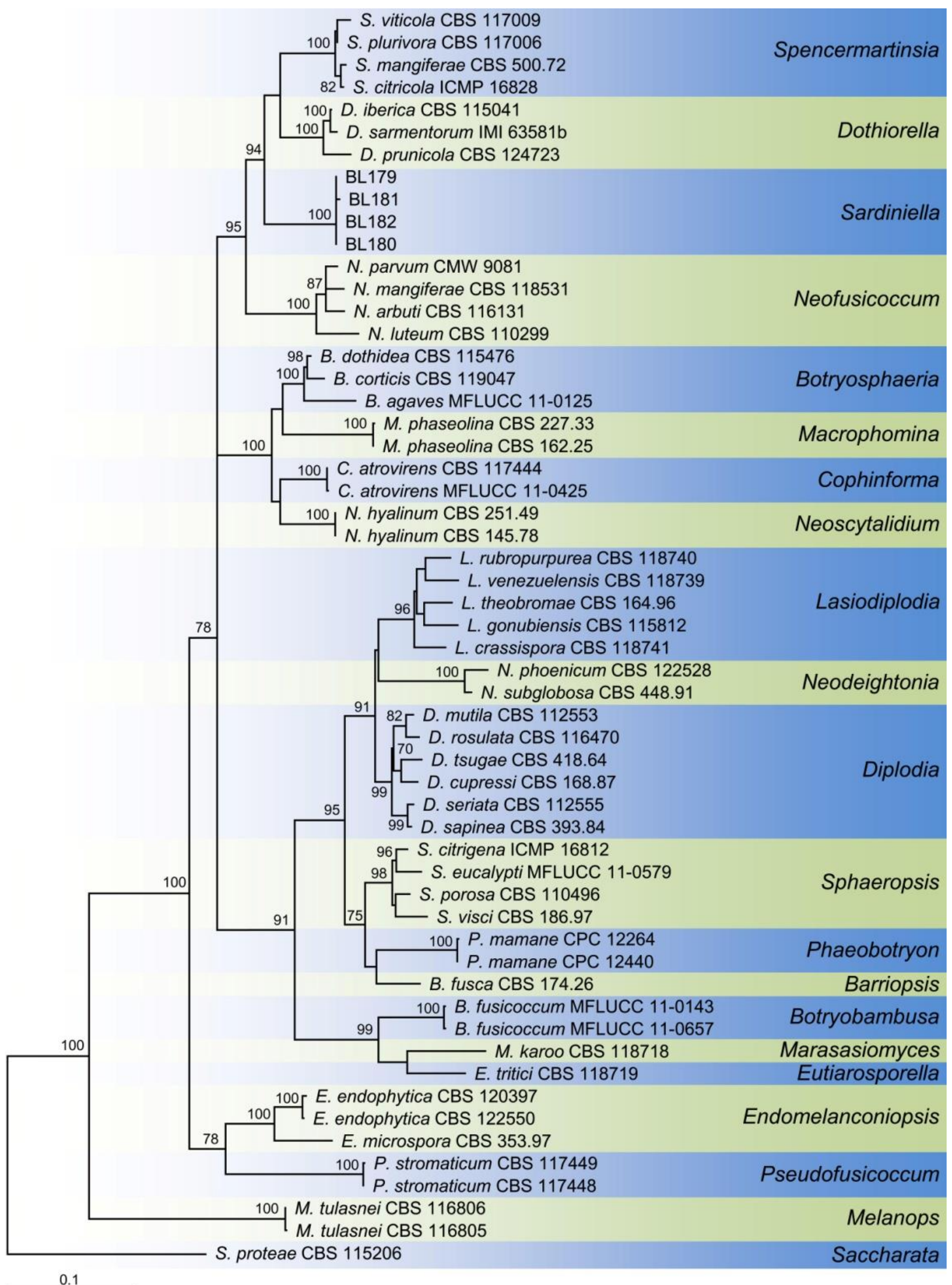

Fig. 2 - Maximum Likelihood tree based on the General Time Reversible model. A discrete Gamma distribution was used to model evolutionary rate differences among sites. The rate variation model allowed for some sites to be evolutionarily invariable. The tree is drawn to scale, with branch lengths measured in the number of substitutions per site. Bootstrap support values in percentage (1000 replicates) are given at the nodes. 


\section{Results}

\section{Symptoms and isolations}

Phytosanitary inspections carried out in three streets in Sassari on 47 European hackberry trees over a two year period revealed the presence of severe disease symptoms typical of Botryosphaeriaceae infections in 14 trees (Fig. 1). The main symptoms were a progressive dieback of twigs and branches, bark necrosis and sunken cankers. Wedge-shaped cankers were seen in sections of affected branches. The trunks of two trees, felled for reasons of public safety, were sectioned at several points in order to examine internal symptoms. These revealed V-shaped necrosis of trunks at collar level and brown vascular streaking visible as spots in cross sections of trunks cut at breast height. Isolation carried out from 22 symptomatic samples yielded a total of 22 morphologically identical colonies belonging to the Botryosphaeriaceae family. Four isolates obtained from four different trees were used as representatives for further molecular studies. No other fungal species were isolated.
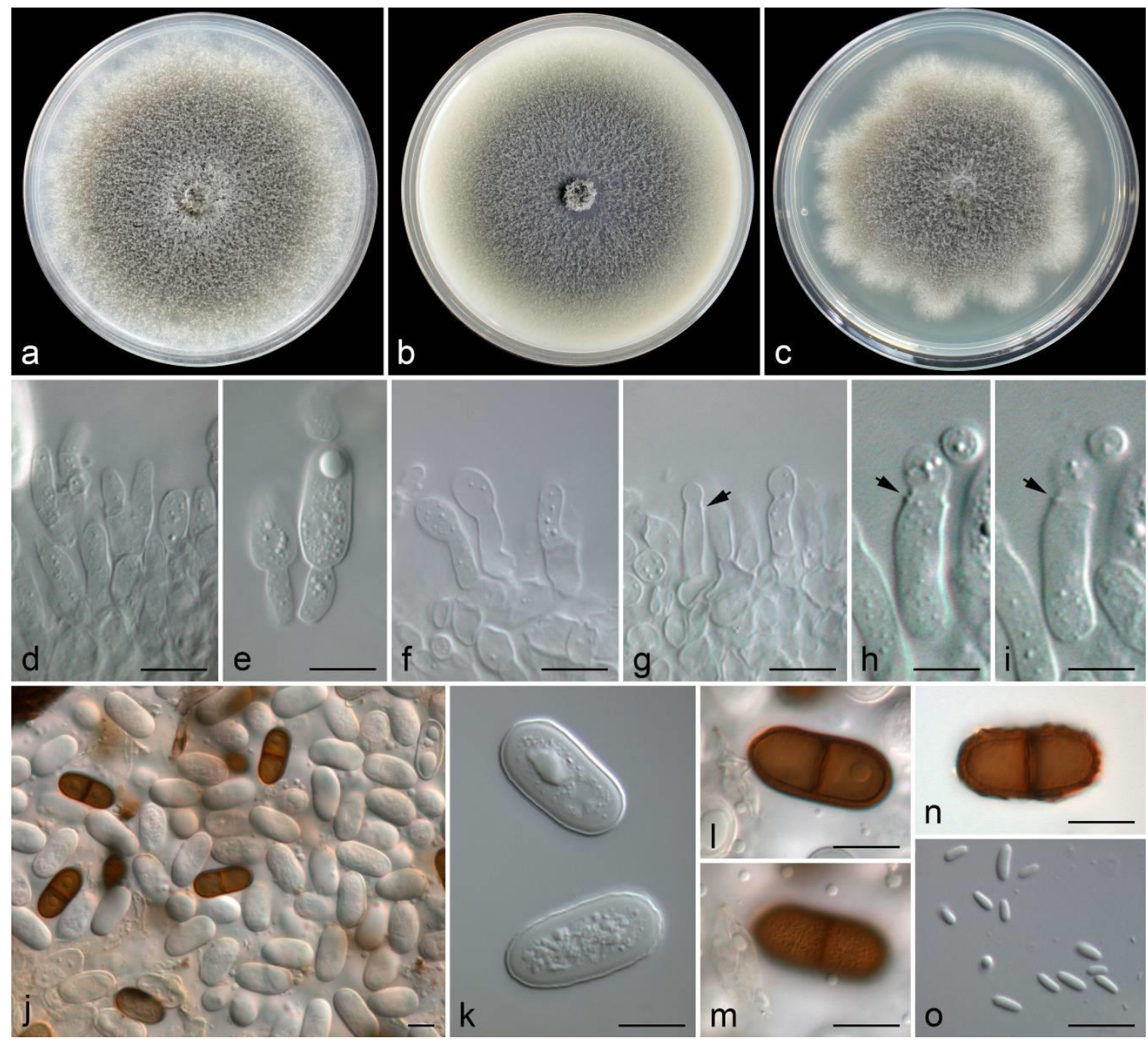

Fig. 3 - Colony morphology of Sardiniella urbana after 7 days growth at $25{ }^{\circ} \mathrm{C}$ on, a. MEA, b. OA and c. PDA. d. Conidiogenous cells developing on branched conidiophores. e. Conidiogenous cells with developing conidia. f. Young conidiogenous cells. g. Percurrently proliferating conidiogenous cell with a single annellide (arrow). h, i. Percurrently proliferating conidiogenous in two different planes of focus to show a single annellide (arrows). j. Hyaline, aseptate and dark-walled, 1-septate conidia. k. Hyaline, aseptate conidia with undulate wall. 1, m. Dark-walled, 1-septate conidium in two different planes of focus to show verruculose inner surface of the wall. n. Verrucose mature conidium. $\mathrm{o}$. Microconidia. Scale bars $\mathrm{d}-\mathrm{g}, \mathrm{j}-\mathrm{O}=10 \mu \mathrm{m} ; \mathrm{h}, \mathrm{i}=5 \mu \mathrm{m}$. 


\section{Phylogenetic analyses}

The combined LSU, ITS and tefl- $\alpha$ dataset alignment contained 1547 characters. Trees and alignments are available at TreeBase S19467. The ML phylogenetic analysis resolved 19 clades with high bootstrap support (96 to 100\%) within the Botryosphaeriaceae corresponding to 18 known genera. The isolates from declining European hackberry trees formed a separate clade with high bootstrap support (100\%) that clustered between Neofusicoccum and Dothiorella.

A comparison of tefl- $\alpha$ sequences revealed polymorphisms among isolates from European hackberry. In particular, the sequence of the isolate BL181 differed by $3 \mathrm{bp}$ from the sequences of the other strains studied. ITS sequences for all isolates were identical.

\section{Taxonomy}

Sardiniella Linaldeddu, A. Alves \& A.J.L. Phillips, gen. nov. MycoBank: MB 817511

Facesoffungi number: FoF 02405

Etymology - Named after the island of Sardinia where it was collected.

Type species - Sardiniella urbana Linaldeddu, A. Alves \& A.J.L. Phillips, sp. nov.

Parasitic on bark and xylem tissues. Sexual morph - not seen. Asexual morph - Conidiomata pycnidial, ostiolate, solitary, black, globose, uniloculate, thick-walled, wall composed of brown walled textura angularis. Conidiophores hyaline, smooth, thin-walled, cylindrical to oblong, branched. Conidiogenous cells hyaline, smooth, cylindrical, holoblastic, proliferating percurrently to form annellides. Conidia ovoid to ellipsoid with obtuse ends, thick-walled, sometimes with an irregular/undulate surface, initially hyaline and aseptate, becoming brown and one septate or rarely two septate with age.

Notes - Phylogenetically Sardiniella is closely related to Neofusicoccum and Dothiorella/Spencermartinsia (Fig. 2). The thick-walled, oblong conidia that become pigmented and 1-septate differentiate Sardiniella from Neofusicoccum. Morphologically, Sardiniella is similar to Diplodia and Dothiorella/Spencermartinsia. However, in Dothiorella, Spencermartinsia and in some species of Diplodia the conidia become pigmented while still attached to the conidiogenous cell and this character was not seen in Sardiniella. In Diplodia, the conidial wall is thicker than in Sardiniella and these two genera are clearly separated phylogenetically.

Sardiniella urbana Linaldeddu, A. Alves \& A.J.L. Phillips, sp. nov.

Fig. 3 MycoBank: MB 817512

Facesoffungi number: FoF 02406

Etymology - the epithet refers to the urban environments, where the species was originally found.

Sexual morph - not seen. Asexual morph - Conidiomata pycnidial, produced on holm oak twigs on $1 / 2$ PDA within 2-4 weeks, ostiolate, solitary, black, globose, uniloculate, thick-walled, wall composed of dark brown textura angularis, lighter in colour towards the inner layers. Conidiophores hyaline, smooth, thin-walled, cylindrical to oblong, branched, 5-11 $\times 3-8 \mu \mathrm{m}$. Conidiogenous cells hyaline, smooth, cylindrical, holoblastic, proliferating percurrently to form annellides, 5-8 $\times 2-3 \mu \mathrm{m}$. Conidia ovoid to ellipsoid, thick-walled sometimes with irregular surface, initially hyaline and aseptate, becoming dark brown and one septate or rarely two septate with age 18.9-(23.5)-26.7 $\times 10.4-(12)-14.5 \mu \mathrm{m},(\bar{x} \pm$ S.D. $=23.5 \pm 1.48 \times 12 \pm 0.89 \mu \mathrm{m}, \mathrm{L} / \mathrm{W}$ $1.97 \pm 0.15 ; \mathrm{n}=50)$. Microconidiogenous cells not seen. Microconidia $2-5 \times 0.5-1.5 \mu \mathrm{m}$, bacilliform, hyaline, smooth, thin-walled, aseptate, produced in the same conidiomata as conidia.

Culture characteristics - All three culture media supported growth of the fungus. Colonies on PDA reaching $82 \mathrm{~mm}$ diameter after 7 days at $25^{\circ} \mathrm{C}$, mycelium velvety and moderately fluffy with an irregular margin, surface initially white and later turning dark olivaceous from the middle of the colony and dark grey in reverse (Fig. 2). On MEA and OA colonies attained $90 \mathrm{~mm}$ diameter 
before 7 days, the white mycelium was generally aerial and floccose on MEA, but appressed, especially at the margin on OA. $40{ }^{\circ} \mathrm{C}$.

Cardinal temperatures - Min. $<5{ }^{\circ} \mathrm{C}$, max. $>35^{\circ} \mathrm{C}$, opt. $25^{\circ} \mathrm{C}$. All isolates failed to grow at

Known distribution - Sassari, Sardinia (Italy).

Habitat - On trunks and cankered branches of European hackberry (Celtis australis).

Material examined - Italy, Sassari, isolated from a branch canker of Celtis australis, 9 September 2013, Benedetto T. Linaldeddu, HOLOTYPE LISE 96308, a dried culture sporulating on Quercus ilex twigs, culture ex-holotype CBS $141580=$ BL179. Other isolates examined are listed in Table 1.

Notes - The conidial wall of $S$. urbana is frequently undulate or irregular. It is not clear if this is a characteristic of the genus or of this particular species.

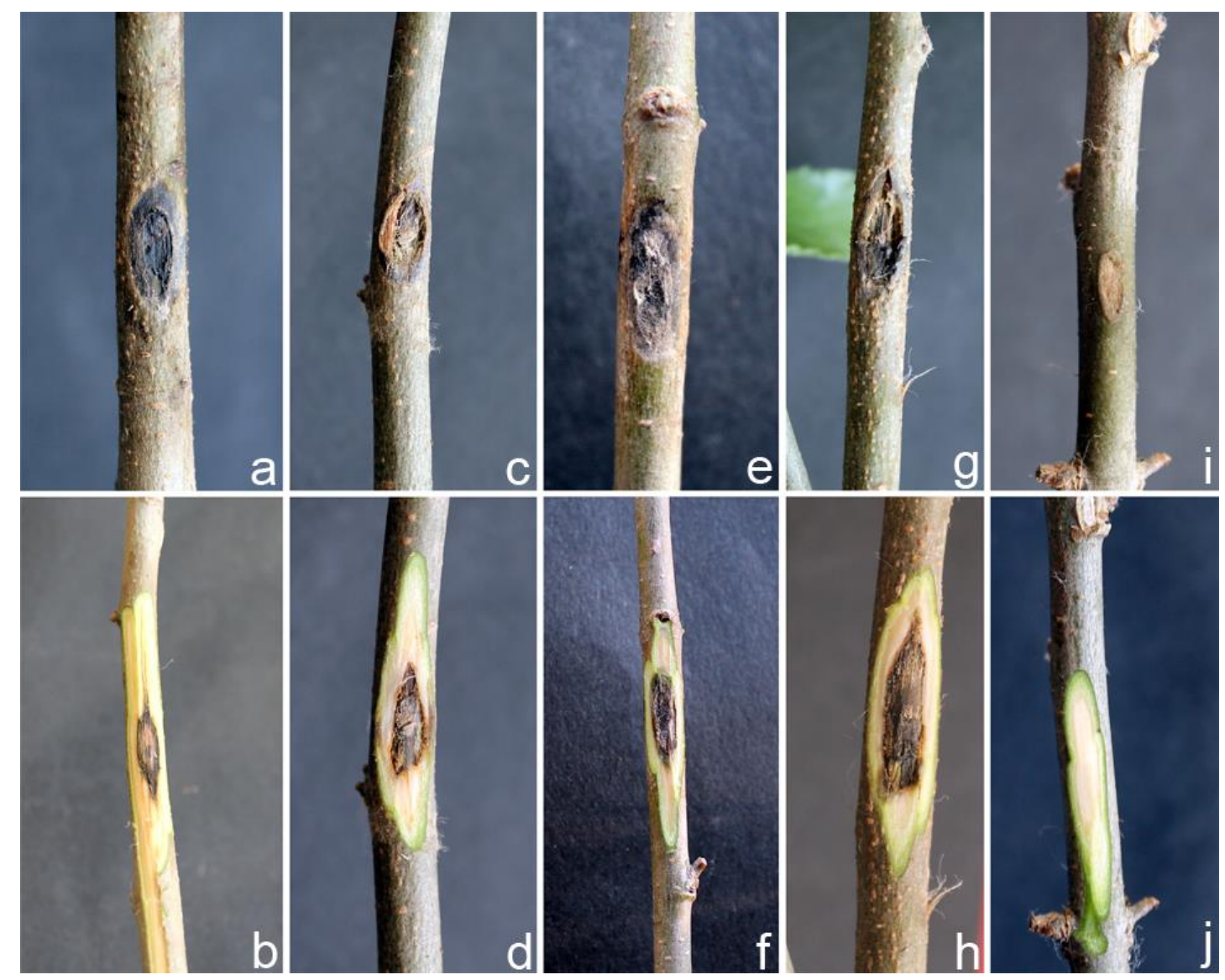

Fig. 4 - Symptoms on European hackberry seedlings 40 days after inoculation with Sardiniella urbana strain BL179 (a, b); BL180 (c, d); BL181 (e, f); BL182 (g, h). Control seedlings (i, j).

\section{Pathogenicity test}

All isolates of $S$. urbana proved to be pathogenic on European hackberry, but different levels of aggressiveness were observed among them. At the end of the experimental period, all seedlings inoculated with fungal mycelial plugs displayed sunken dark brown bark lesions that spread up and down the stem from the inoculation site and also penetrated a few millimeters into the sapwood (Fig. 4). The average lesion size differed significantly between isolates (d.f. $=3 ; F=48.78, P<$ $0.001)$ e.g. the lesions caused by BL182 (mean \pm S.D. $=2.9 \pm 0.4 \mathrm{~cm}$ ) were significantly larger than those caused by BL181 $(2.2 \pm 0.3 \mathrm{~cm})$, BL179 $(2.1 \pm 0.3 \mathrm{~cm})$ and BL180 $(1.1 \pm 0.3 \mathrm{~cm})$. The control seedlings remained asymptomatic with only a trace of inner bark discoloration as a wound response at the inoculation point. The pathogen was successfully re-isolated from symptomatic wood and inner bark tissues from all inoculated seedlings, thus fulfilling Koch's postulates. 


\section{Discussion}

In this study, Sardiniella is introduced as a new genus in the Botryosphaeriaceae. The type species, S. urbana, was isolated from diseased European hackberry trees in an urban environment on the island of Sardinia. Results of phylogenetic analyses provide robust evidence that Sardiniella belongs to a separate genus in the Botryosphaeriaceae and together with its close allies form a major clade (Fig. 2). This clade includes four genera Dothiorella, Neofusicoccum, Sardiniella and Spencermartinsia that morphologically are readily distinguishable by conidial shape. The thinwalled, obovoid to fusiform conidia of Neofusicoccum, clearly separate this genus from Sardiniella. The hyaline, thick-walled conidia that become pigmented and 1-septate resemble Dothiorella and Spencermartinsia, but in Sardiniella the conidia do not become coloured while attached to the conidiogenous cell. Colouration of conidia before dehiscence is a feature that distinguishes Dothiorella and Spencermartinsia from all other genera in the Botryosphaeriaceae.

European hackberry is the most popular urban tree in the city of Sassari, with more than 1,450 trees planted along the main streets, in parks and in gardens (Achenza 1995). To date, little information is available about the occurrence, distribution and severity of damage caused by fungal pathogens on European hackberry worldwide. Recently, a foliar disease caused by Sirosporium celtidis and a decline caused by Inonotus rickii were detected on European hackberry in Italy (Cacciola 2000, Annesi et al. 2003).

In this study, out of 47 trees investigated 14 were found to be severely damaged by $S$. urbana infections. The site factors that may have contributed to the outbreak of $S$. urbana infections still remain unknown as well as its ecology. In recent years, reports of epidemic attacks of Botryosphaeriaceae species in different natural ecosystems have gradually increased in Sardinia (Andolfi et al. 2012, Alves et al. 2014, Linaldeddu et al. 2014). These findings emphasize how species in this family represent a growing threat to forest trees in Mediterranean region in both urban and natural environments.

All four isolates of this newly recognized species proved to be pathogenic to European hackberry causing lesions on the bark and brown streaks in the wood congruent with field observations. The variability in aggressiveness as well as the occurrence of polymorphisms in the tefl- $\alpha$ sequences among isolates of $S$. urbana detected in this study suggests the need to extend the research about the intraspecific variability of this new member of Botryosphaeriaceae to assess the presence of pathotypes and evolutionary lineages. Intraspecific variability has been reported for other Botryosphaeriaceae species such as Diplodia corticola (Linaldeddu et al. 2013), Diplodia sapinea (de Wet et al. 2002) and Diplodia seriata (Elena et al. 2015).

The findings of this study emphasize the primary role played by this new species in the etiology of the observed decline in European hackberry trees. They also underline the fact that infection represents a potential risk to public safety in urban environments.

\section{Acknowledgements}

This work was in part supported by grants from the municipality of Sassari, project: "Problemi sanitari in alberate di Bagolaro della Città di Sassari". Artur Alves acknowledges financial support from European Funds through COMPETE and National Funds through the Portuguese Foundation for Science and Technology (FCT) to CESAM (UID/AMB/50017/2013 POCI-01-0145-FEDER-007638) and himself (FCT Investigator Programme - IF/00835/2013).

\section{References}

Achenza A. 1995 - Indagine sulle specie arboree ed arbustive del patrimonio vegetale della città di Sassari. Bollettino della Società Sarda di Scienze Naturali 30, 131-150.

Alves A, Linaldeddu BT, Deidda A, Scanu B, Phillips AJL. 2014 - The complex of Diplodia species associated with Fraxinus and some other woody hosts in Italy and Portugal. Fungal Diversity 67, 143-156. 
Andolfi A, Maddau L, Cimmino A, Linaldeddu BT, Franceschini A, Serra S, Basso S, Melck D, Evidente A. 2012 - Cyclobotryoxide, a phytotoxic metabolite produced by the plurivorous pathogen Neofusicoccum australe. Journal of Natural Products 75, 1785-1791.

Annesi T, Coppola R, Motta E. 2003 - Decay and canker caused by Inonotus rickii spreading on more urban tree species. Forest Pathology 33, 405-412.

Begoude BAD, Slippers B, Wingfield MJ, Roux J. 2010 - Botryosphaeriaceae associated with Terminalia catappa in Cameroon, South Africa and Madagascar. Mycological Progress 9, $101-123$.

Cacciola SO. 2000 - A foliar disease of European hackberry endemic in Sicily. Plant Disease 84, 492.

Crous PW, Gams W, Stalpers JA, Robert V, Stegehuis G. 2004 - MycoBank: an online initiative to launch mycology into the $21^{\text {st }}$ century. Studies in Mycology 50, 19-22.

Crous PW, Müller MM, Sánchez RM, Giordano L, Bianchinotti MV, Anderson FE, Groenewald JZ. 2015 - Resolving Tiarosporella spp. allied to Botryosphaeriaceae and Phacidiaceae. Phytotaxa 202, 073-093.

Crous PW, Slippers B, Wingfield MJ, Rheeder J, Marasas WFO, Philips AJL, Alves A, Burgess T, Barber P, Groenewald JZ. 2006 - Phylogenetic lineages in the Botryosphaeriaceae. Studies in Mycology 55, 235-253.

Crous PW, Wingfield MJ, Guarro J, Cheewangkoon R, van der Bank M, Swart WJ, Stchigel AM, Cano-Lira JF, Roux J, Madrid H, Damm U, Wood AR, Shuttleworth LA, Hodges CS, M Munster8, de Jesús Yáñez-Morales M., Zúñiga-Estrada L, Cruywagen EM, de Hoog GS, Silvera C, Najafzadeh J, Davison EM, Davison PJN, Barrett MD, Barrett RL, Manamgoda DS, Minnis AM, Kleczewski NM, Flory SL, Castlebury LA, Clay K, Hyde KD, MaússeSitoe SND, Chen S, Lechat C, Hairaud M, Lesage-Meessen L, Pawłowska J, Wilk M, Śliwińska-Wyrzychowska A, Mętrak M, Wrzosek M, Pavlic-Zupanc D, Maleme HM, Slippers B, Mac Cormack WP, Archuby DI, Grünwald NJ, Tellería MT, Dueñas M, Martín MP, Marincowitz S, de Beer ZW, Perez CA, Gené J, Marin-Felix Y, Groenewald JZ. 2013 - Fungal Planet description sheets: 154-213. Persoonia 31, 188-296.

de Wet J, Wingfield MJ, Coutinho TA, Wingfield BD. 2000 - Characterization of Sphaeropsis sapinea isolates from South Africa, Mexico and Indonesia. Plant Disease 84, 151-156.

Elena G, Garcia-Figueres F, Reigada S, Luque J. 2015 - Intraspecific variation in Diplodia seriata isolates occurring on grapevines in Spain. Plant Pathology 64, 680-689.

Gramaje D, Agustí-Brisach C, Pérez-Sierra A, Moralejo E, Olmo D, Mostert L, Damm U, Armengol J. 2012 - Fungal trunk pathogens associated with wood decay of almond trees on Mallorca (Spain). Persoonia 28, 1-13.

Hall TA. 1999 - BioEdit: a user-friendly biological sequence alignment editor and analysis program for Windows 95/98/NT. Nucleic Acids Symposium Series 41, 95-98.

Hyde KD, Nilsson RH, Alias SA, Ariyawansa HA, Blair JE, Cai L, de Cock AWAM, Dissanayake AJ, Glockling SL, Goonasekara ID, Gorczak M, Hahn M, Jayawardena RS, van Kan JAL, Laurence MH, Lévesque CA, Li XH, Liu JK, Maharachchikumbura SSN, Manamgoda DS, Martin FN, McKenzie EHC, McTaggart AR, Mortimer PE, Nair PVR, Pawłowska J, Rintoul TL, Shivas RG, Spies CFJ, Summerell BA, Taylor PWJ, Terhem RB, Udayanga D, Vaghefi N, Walther G, Wilk M, Wrzosek M, Xu JC, Yan JY, Zhou N, 2014. One stop shop: backbones trees for important phytopathogenic genera: I. Fungal Diversity 67: 21-125.

Inderbitzin P, Bostock RM, Trouillas FP, Michailides TJ. 2010 - A six-locus phylogeny reveals high species diversity in Botryosphaeriaceae from California almond. Mycologia 102, $1350-1368$.

Jayasiri SC, Hyde KD, Ariyawansa HA, Bhat DJ, Buyck B, Cai L, Dai YC, Abd-Elsalam KA, Ertz D, Gibertoni TB, Hidayat I, Jeewon R, Jones EBG, Karunarathna SC, Kirk P, Li WJ, Liu JK, Luangsa-ard JJ, Maharachchikumbura SSN, Manamgoda DS, McKenzie EHC, Moncalvo JM, Ghobad-Nejhad M, Nilsson H, Pang KL, Pereira OL, Raspé O, Rollins AW, Romero AI, Salazar JAE, Stephenson S, Suetrong S, Taylor JE, Tsui CKM, Vizzini A, 
Abdel-Wahab MA, Wen TC, Boonmee S, Dai DQ, Daranagama DA, Dissanayake AJ, Ekanayaka AH, Hongsanan S, Jayawardena RS, Perera RH, Phookamsak R, De Silva NI, Thambugala KM, Tian Q, Wanasinghe DN, Wijayawardene NN, Zhao RL, Kang JC, Promputtha I. 2015 - The Faces of Fungi database - A unique perspective: Fungal names linked with morphology, phylogeny and human impacts. Fungal Diversity 74, 3-18.

Linaldeddu BT, Deidda A, Scanu B, Franceschini A, Alves A, Abdollahzadeh J, Phillips AJL. 2016 - Phylogeny, morphology and pathogenicity of Botryosphaeriaceae, Diatrypaceae and Gnomoniaceae associated with branch diseases of hazelnut in Sardinia (Italy). European Journal of Plant Pathology (DOI: 10.1007/s10658-016-0912-z).

Linaldeddu BT, Deidda A, Scanu B, Franceschini A, Serra S, Berraf-Tebbal A, Zouaoui Boutiti M, Ben Jamâa ML, Phillips AJL. 2015 - Diversity of Botryosphaeriaceae species associated with grapevine and other woody hosts in Italy, Algeria and Tunisia, with descriptions of Lasiodiplodia exigua and Lasiodiplodia mediterranea sp. nov. Fungal Diversity 71, 201214.

Linaldeddu BT, Franceschini A, Alves A, Phillips AJL. 2013 -Diplodia quercivora sp. nov.: a new species of Diplodia found on declining Quercus canariensis trees in Tunisia. Mycologia 105, 1266-1274.

Linaldeddu BT, Scanu B, Maddau L, Franceschini A. 2014 - Diplodia corticola and Phytophthora cinnamomi: the main pathogens involved in holm oak decline on Caprera island (Italy). Forest Pathology 44, 191-200.

Liu JK, Phookamsak R, Doilom M, Wikee S, Li YM, Ariyawansha H, Boonmee S, Chomnunti P, Dai DQ, Bhat JD, Romero AI, Zhuang WY, Monkai J, Jones EBG, Chukeatirote E, Ko Ko TW, Zhao YC, Wang Y, Hyde KD. 2012 - Towards a natural classification of Botryosphaeriales. Fungal Diversity 57, 149-210.

Lynch SC, Eskalen A, Zambino PJ, Mayorquin JS, Wang DH. 2013 - Identification and pathogenicity of Botryosphaeriaceae species associated with coast live oak (Quercus agrifolia) decline in southern California. Mycologia 105, 125-140.

Marques MW, Lima NB, Morais Jr MA de, Barbosa MAG, Souza BO, Michereff SJ, Phillips AJL, Câmara MPS. 2013 - Species of Lasiodiplodia associated with mango in Brazil. Fungal Diversity 61, 181-193.

Mayorquin JS, Eskalen A, Downer AJ, Hodel DR, Liu A. 2012 - First report of multiple species of the Botryosphaeriaceae causing bot canker disease of Indian laurel-leaf fig in California. Plant Disease 96, 459.

O'Donnell K. 1993 - Fusarium and its near relatives. Edited by D. R. Reynolds \& J. W. Taylor. Wallingford, UK: CAB International. In The Fungal Holomorph: Mitotic, Meiotic and Pleomorphic Speciation in Fungal Systematics, pp. 225-233.

Page RD. 1996 - TreeView: an application to display phylogenetic trees on personal computers. Computer Applications in the Biosciences 12, 357-358.

Phillips AJL, Alves A, Abdollahzadeh J, Slippers B, Wingfield MJ, Groenewald JZ, Crous PW 2013 - The Botryosphaeriaceae: genera and species known from culture. Studies in Mycology 76, 51-167.

Phillips AJL, Alves A, Pennycook SR, Johnston PR, Ramaley A, Akulov A, Crous PW. 2008 Resolving the phylogenetic and taxonomic status of dark-spored teleomorph genera in the Botryosphaeriaceae. Persoonia 21, 29-55.

Rojas EI, Herre EA, Mejía LC, Arnold AE, Chaverri P, Samuels GJ. 2008 - Endomelanconiopsis, a new anamorph genus in the Botryosphaericeae. Mycologia 100, 760-775.

Slippers B, Boissin E, Phillips AJL, Groenewald JZ, Lombard L, Wingfield MJ, Postma A, Burgess T, Crous PW. 2013 - Phylogenetic lineages in the Botryosphaeriales: a systematic and evolutionary framework. Studies in Mycology 76, 31-49.

Tamura K, Stecher G, Peterson D, Filipski A, Kumar S. 2013 - MEGA6: molecular evolutionary genetics analysis version 6.0. Molecular Biology and Evolution 30, 2725-2729. 
Taylor K, Barber PA, Hardy GEStJ, Burgess TI. 2009 - Botryosphaeriaceae from tuart (Eucalyptus gomphocephala) woodland, including descriptions of four new species. Mycological Research 113, 337-353.

Thompson JD, Gibson TJ, Plewniak F, Jeanmougin F, Higgins DG. 1997 - The CLUSTAL_X windows interface: flexible strategies for multiple sequence alignment aided by quality analysis tools. Nucleic Acids Research 25, 4876-4882.

White TJ, Bruns T, Lee S, Taylor J. 1990 - Amplification and direct sequencing of fungal ribosomal RNA genes for phylogenetics. In: PCR Protocols, a Guide to Methods and Applications (eds. MA Innis, DH Gelfand, JJ Sninsky and J White) Academic Press. San Diego, Ca, USA 315-322.

Zlatković M, Keča N, Wingfield MJ, Jami F, Slippers B. 2016 - Botryosphaeriaceae associated with the die-back of ornamental trees in the Western Balkans. Antonie Van Leeuwenhoek $109,543-64$. 